\title{
Regional Economic Integration in Africa: Challenges and Prospects
}

Martha Belete Hailu *

\section{Abstract}

Africa has witnessed various efforts of economic integration at the continental and regional levels. While the idea of regional integration is as old as the Organization of African Unity now renamed as African Union, recent summits have reaffirmed Africa's commitment toward boosting intra-Africa trade and integration. With the grand aim of forming a continental economic community (African Economic Community) in the future, African countries aspire to use the various regional economic communities as building blocs. Despite such endeavors, however, the continent's economy has remained fragmented, inter alia, due to low level of infrastructure development and the state-centric nature of the integration efforts. The overlapping multiple memberships of countries to the regional groupings has complicated the integration effort. The absence of clear rule on the relationship between the existing regional economic communities and the 'to-be-formed' African Economic community has also contributed to the uncertainty in the integration process. In view of these challenges, I argue that the focus on speeding up the formation of the continental wide free trade area (FTA) does not seem timely; and the focus should rather be redirected at strengthening the regional economic communities. These pursuits meanwhile call for addressing the legal and non legal issues that are important steps in bringing the continent closer to integration.

\section{Key terms}

Regional Integration, African Economic Community, Continental

Free Trade Area, Intra Africa Trade, Regional Economic

Communities

DOI http://dx.doi.org/10.4314/mlr.v8i2.2

* LL.B (AAU), LL.M (UWC), PhD Candidate (Martin Luther University of Halle Wittenberg, Germany). I am grateful for the comments I received from internal and external reviewers. All errors remain mine. E-mail: martha.b.hailu[at]gmail.com 


\section{Introduction}

For several years, there is a movement towards regional economic integration throughout the world. A regional integration arrangement can be regarded as preferential (usually reciprocal) agreement among countries that reduces barriers to economic and non-economic transactions. ${ }^{1}$ It is the unification of different economies of states in order to promote and facilitate the free movement of goods and services within themselves. All regional integration agreements have the objective of reducing or eliminating barriers between their members. However, they also exhibit a wide range of variation. In terms of depth, their variation depends on the level of integration undertaken by member countries.

The different stages of integration were originally formulated by Professor Bela Balassa in 1961. According to Balassa, the first stage of integration is Free Trade Area which leads to the abolition of tariffs (and quantitative restrictions) between the participating countries, while each country retains its own tariffs against non members. ${ }^{2}$ In free trade areas, states have the autonomy to maintain their individual tariff and other measures against non member countries. The second stage which elevates the level of integration a step forward is customs union and it requires common external tariff maintained by its members. As described by Balassa, establishing a customs union goes beyond the suppression of discrimination in the field of commodity movements within the union, and further involves the equalization of tariffs in trade with nonmember countries. ${ }^{3}$

At the third stage of economic integration common market is formed whereby, not only trade restrictions but also restrictions on factor movements like labor and capital are abolished. ${ }^{4}$ The pursuits of economic integration can further lead to economic union, as distinct from a common market which combines the suppression of restrictions on commodity and factor policies, in order to remove discrimination that was due to disparities in these policies. ${ }^{5}$ The countries in an economic union get a common monetary system and policies. The European Union, through its adoption of a common monetary policy and using of the Euro as a common currency,

\footnotetext{
${ }^{1}$ UNECA, (2004), Assessing Regional Integration in Africa, Addis Ababa, $\mathrm{p} 9$.

${ }^{2}$ Bela Balassa (1961), The Theory of Economic Integration, Greenwood Press, p. 174.

${ }^{3}$ Ibid.

${ }^{4}$ Ibid.

${ }^{5}$ Id., p. 175.
} 
has furthered the integration process into an economic union. Finally, total economic integration presupposes the unification of monetary, fiscal, social and countercyclical policies and requires the setting up of a supra national authority whose decisions are binding for member states. ${ }^{6}$

While many of the regional integration schemes in the world are based on such formulation, the Balassan stages are not necessarily expected to be pursued with sequential rigidity, and there is no compelling reason to expect a FTA to 'evolve' into a CU or toward total economic integration. ${ }^{7}$ One should also keep in mind that the names given to some regional arrangements may not necessarily reflect the level of integration reached by the arrangements. A good example here is the Common Market for Eastern and Southern Africa (COMESA). Despite the use of the term 'Common Market', COMESA has only recently launched a Customs Union and it has not yet attained Common Market level integration.

Countries wish to join their economies for various reasons, some of which include attraction of foreign investment, enhancing cooperation, fostering security and generally attaining economic development. With these aims in mind, governments sign and become members of multiple regional integration schemes. However, some of these integration schemes simply reflect the desire but not always the political will to capture the economic gains and international negotiating strength that regionalization can bring. ${ }^{8}$

Africa is not peculiar in this respect. A number of initiatives have been launched in the continent to bring economic and political integration. These integration efforts have been undertaken concurrently at continental and regional levels. On the continental level, the effort of integration started with the adoption of the OAU Charter in 1963 which envisions initiatives to integrate the Africa region for the promotion of economic and social development. The integration effort in Africa was taken a step further, at least on paper, through the adoption of the Lagos Plan of Action (LPA) in 1980. The failure of African countries to implement the LPA did not stop the governments from wishing to have a continent wide economic and political integration. That is why, in 1991, the Heads of States decided to give another try for the talk of integration and revived the 1980 LPA through the adoption of the Treaty Establishing the African Economic Community

\footnotetext{
${ }^{6}$ Ibid.

${ }^{7}$ Andrew T Guzman and Joost H.B.Pauwelyn (2009), International Trade Law, Kluwer Law International, p.330.

${ }^{8}$ R.H. Folsom, M.G Wallace and J.A. Spanogle (2000), International Trade and Investment in a Nutshell, ( $2^{\text {nd }}$ ed.), St Paul Minn, West Group, p 393.
} 
(Abuja Treaty). The Abuja treaty, which entered into force in 1994, aims at forming an African Economic Community composed of all African states over a period of 34 years and using six stages of integration. The preexisting Regional Economic Communities (RECs) are to be used as a building block for the establishment of the AEC.

Parallel to the continental wide movement, there are various RECs in the different corners of the continent. In the Eastern and Southern parts of the continent, the Common Market for Eastern and Southern Africa (COMESA) replaced a Preferential Trade Agreement (PTA) and the Southern African Development Coordination Conference changed into the Southern African Development Community (SADC) whereas the Mahgreb and Mashraq groups have renewed their integration efforts in the Northern Part of Africa. ${ }^{9}$ We have also the Economic Community of West African States (ECOWAS), Economic Community of Sahelo-Saharian States (CENSAD), the Intergovernmental Authority on Development (IGAD) and the East African Community (EAC).

Despite all these efforts at integration, the continent still remains to be fragmented as a market, and its aspirations toward political unity is far from being real. This article looks into the various factors that contributed to the failure of integration in the region and tries to suggest some measures to be undertaken to have a viable economic integration; with the focus being on regional trade integration.

In this regard, the first section briefly highlights the political theories of regional integration. It also discusses some of the benefits of regional integration. Section 2 looks into regional integration in Africa. It looks into the current economic and political conditions in the continent, and highlights continental-wide movements toward integration. Few of the RECs are also briefly discussed. The third section will focus on the challenges faced in the efforts at integrating African countries. It tries to identify legal as well as non legal impediments. The last section looks into the way forward, followed by concluding remarks.

\footnotetext{
${ }^{9}$ Maurice Schiff and Alan Winters (2003), Regional Integration and Development,
} (World Bank, Washington DC), p. 6. 


\section{Background: Theories of Regional Integration}

Political theories of regional integration emerged to mainly explain European integration. These theoretical approaches discuss the key factors that facilitate the achievement of regional integration. ${ }^{10}$ The first approach, Neo-Functionalism, was developed by Ernst Haas. He developed the concept of spillover, which 'refers to a situation in which a given action, related to a specific goal, creates a situation in which the original goal can be assured only by taking further actions, which in turn create a further condition and a need for more action, and so forth'. ${ }^{11}$

According to Haas, Regional integration flows from process of spillover in which the integrating of an individual sector is built by aiming to achieve the process of integration in other sectors. The liberalization of trade within a customs union would lead to harmonization of economic policies and eventually spillover into political areas and lead to the creation of some kind of political community. ${ }^{12}$ This theory also assumed that there will be a decline in the importance of nationalism and the nation state, and that elected officials and interest groups within states would see it in their interest to have market and political integration at a higher level. Hence, regional integration would be seen as a process whereby political actors in several distinct national setting are persuaded to shift their loyalties, expectations and political activities toward a new centre, whose institutions possess jurisdiction over pre-existing states. ${ }^{13}$

An alternative theory of integration is intergovernmentalism. This theory was initially proposed by Stanley Hoffmann and refined by Andrew Moravcsik. The theory of intergovernmentalism suggests that governments control the level and speed of integration. Hoffman argued that every international system owes its inner logic and its unfolding to the diversity of

${ }^{10}$ Thanawat Pimoljinda, Theoretical Discussion on Regional Integration: EUASEAN Perspective,

$<$ http://www.academia.edu/388618/Theoretical_Discussion_on_Regional_Integr ation_EU-ASEAN_Perspective $>$.

${ }^{11}$ Leon N. Lindberg (1993), The Political Dynamics of European Economic Integration, as cited by Finn Laursen (February 2008), Theory and Practice of Regional Integration, 8 Jean Monnet/Robert Schuman Paper Series 3, p. 4.

12 Ernst B. Haas (1958), The Uniting of Europe: Political, Social and Economic Forces 1950-1957, as cited by , Finn Laursen (February 2008), Theory and Practice of Regional Integration, 8 Jean Monnet/Robert Schuman Paper Series 3, p. 4.

${ }^{13}$ Ibid. 
domestic determinants, geo-historical situations, and outside aims among its units. $^{14}$ The diversity sets limit to the degree to which the 'spillover' process can function. "It restricts the domain in which the logic of functional integration operates to the area of welfare". 15 Hoffmann advanced the suggestion that "in areas of key importance to the national interest, nations prefer the certainty, or the self-controlled uncertainty, of national selfreliance, to the uncontrolled uncertainty" of integration. ${ }^{16}$

Moravcisk, in advancing liberal intergovernmentalism, argues that integration goes as far as member states want it to go and European institutions exist due to the deliberate will of member states to satisfy their interests and are instruments for achieving member states' objectives. ${ }^{17}$ For liberal intergovernmentalists, the member states of a regional integration arrangement (e.g EU member states) are unitary rational actors that are in control of the process of integration, and they believe that the institutions do not play an important role in big decisions. ${ }^{18}$ Institutionalists criticize intergovernmentalists for the latter's failure to attribute an important role for institutions.

The economic theory of regional integration, on the other hand, focuses on market driven integration process and it does not emphasize the importance of institutional and political demand. The liberal economic theoretical framework is the basis for the economic theory of integration. One aspect of the economic theory tells us that regional integration leads to trade creation. It is believed that regional trade liberalization will create significant economic growth within the region concerned which can, in turn, generate more trade with the rest of the world. ${ }^{19}$ According to this view,

${ }^{14}$ Stanley Hoffman (1966), "Obstinate or Obsolete? The Fate of the Nation State and the Case of Western Europe", 95 Daedalus, as cited by Finn Laursen (February 2008), "Theory and Practice of Regional Integration", 8 Jean Monnet/Robert Schuman Paper Series 3, p. 5.

15 Ibid.

16 Ibid.

17 Alina-Stefania Ujupan (September 2006), Reconciling Theories of Regional Integration: A third way Approach, a paper presented at the Third Pan European Conference of European Consortium for Political Research Standing Group on EU Politics, Bilgi University, Istanbul, p. 4.

${ }^{18}$ Finn Laursen (February 2008), Theory and Practice of Regional Integration, 8 Jean Monnet/Robert Schuman Paper Series 3, p. 9.

${ }^{19}$ Peter Van den Bossche (2005), The Law and Policy of the World Trade Organization: Text, Cases and Materials, Cambridge University Press, p. 651. 
regional integration has a positive impact as it creates trade among the member countries. In line with this view it is stated that integration has the effect of replacing expensive domestic production with cheaper imports from the partner country. ${ }^{20}$

However, regional integration may also have the effect of trade diversion. Various studies on regional economic integration have shown that the trade creation effects may be smaller than trade diversion effects of regional integration as trade between the member countries replaces trade between the members and non members. ${ }^{21}$ It diverts trade by replacing initially cheaper imports from a non member country with more expensive imports from a member country within the region. ${ }^{22}$ Trade diversion results in low rate of competition and higher prices to consumers which will ultimately lead to a welfare loss to the community as a whole. Hence it can be concluded that regional integration has both negative as well as positive impacts and that the positive impact will materialize 'only when trade creation dominates trade diversion'-an outcome that cannot be determined in advance $^{123}$

When trade creation effect of regional integration dominates the trade diversion, it is believed to have diverse benefits. Some of these benefits include new trade opportunities, larger markets, increased competition and increased foreign direct investment (FDI) flow in the region. These benefits build upon the theory of liberal capitalism pursued by Western countries and currently spreading to most parts of the world. In recent years, however, there seems to be a shift from liberal capitalism to various levels of state intervention in the economy. ${ }^{24}$ In view of the fact that countries such as China and India, are major economic allies of many of the African countries, the impact of their economic policies will be reflected in the integration process of these countries. However, the discussion in this paper will be

${ }^{20}$ UNECA supra note 1, p.7.

${ }^{21}$ Bossche, supra note 19, p. 651.

${ }^{22}$ Dirk Hansohm (2002), Potentials of Regional Integration in Africa, also available at $<$ http://www.nepru.org.na $>$.

${ }^{23}$ UNECA supra note 1, p.11.

${ }^{24}$ See for example, Adrian Wooldrdge (January 21, 2012), State Capitalism, The Economist and Ian Bremer, (2010), The End of the Free Market: Who wins the War Between States and Corporations?, (Penguin Group, USA) on the gradual shift of policies of states from liberal capitalism to state capitalism where there is more involvement of the state in the economic activities. 
confined to the benefits of regional integration on the basis of liberal capitalism, setting aside discussions on new developments.

Regional integration schemes benefit countries especially in situations when those countries are small and represent small markets. Under such conditions, regional integration will enable the member countries to combine markets, enabling firms to expand and markets to be more competitive. ${ }^{25} \mathrm{An}$ integrated market encourages competition among producers and provides scale benefits in production and more opportunities for specialization. ${ }^{26}$ This in turn will attract foreign investment to the region. The existence of regional block may influence the direction of foreign investment in various ways. With the formation of a block, the market size increases; and studies have indicated that market size and growth attracts foreign investors. ${ }^{27}$ The existence of regional integration may influence the direction of foreign investment. It encourages foreign investors to engage in tariff jumping-that is, investing in one member country in order to trade freely with all members-expanding investments by local and foreign investors. ${ }^{28}$

However, the positive link between regional economic integration and investment growth is not immediately clear ${ }^{29}$ as several factors influence the decision making of investors as to where to invest. An important factor in this regard is whether regional economic integration has contributed to favourable investment climate in the host nation. Apart from market size and growth, other factors like policy credibility influence the decision of investors to invest in a country. Improving the economic management or providing incentives may not be enough to gain investor confidence if the country has a history of bad policies. In this regard, signing regional integration agreement will enable the country to gain trust of investors as the

${ }^{25}$ UNECA supra note 1, p. 12.

${ }^{26}$ Colin McCarty (2011), African Regional Economic Integration: Is the Paradigm Relevant and Appropriate?, in C. Hermann and JP Terhechte (eds.), European Yearbook of International Economic Law, p. 350.

27 A case in point is the surge of FDI from the United States to the newly formed European Economic Community in the 1960s. It is believed that the integration of the European countries and enlargement of the market size as a result, was a major factor driving investors from the US to the EEC. See Balasubramanyam, V., and Greenaway David (1993), Regional Integration agreements and Foreign Direct Investment, in Kym Anderson and Richard Blackhurst, Regional Integration and the World Trading System, Washington DC. World Bank, p.147

${ }^{28}$ UNECA supra note 1, pp. 12-13.

${ }^{29}$ Schiff and Winters, supra note 9. 
agreement will help to lock in reforms made under the regional agreement. ${ }^{30}$ In such conditions, it cannot be denied that an integration scheme, which is properly designed and managed, can improve the investment climate, especially if it addresses infrastructure development of the region. ${ }^{31}$ Larger markets, more competition and improved policy credibility are results of regional integration arrangement, and these settings enhance the incentive for investment, thereby warranting the conclusion that regional integration promotes the economic growth and poverty alleviation pursuits of member countries.

Regional integration (RI) is also seen as a means of achieving peace and security among the member countries. RI is not all about the dismantling of tariff and non tariff barriers among the members. Rather, more positive action will be required from the member countries as deeper integration will require "policy harmonization which entails replacement of national policies with common policy and coordination of national policies". 32 Policy harmonization requires the attainment of common understanding on very essential economic points through discussion, which is possible when there is a smooth relationship between the member countries. There is considerable direct and indirect evidence which indicates that regional integration arrangements can promote regional peace and ultimately lead to political union. ${ }^{33}$

Another benefit that can accrue from regional integration is increased bargaining power in multilateral negotiations. For some countries, regionalism relates to collective action in the course of addressing problems with regard to economic development or security. For these countries, building a collective bargaining capacity to negotiate effectively on multilateral trade negotiation fora is an important consideration for

${ }^{30}$ Id., p, 108.

31 McCarthy, Supra note 26, p. 351.

${ }^{32}$ Nsongurua J. Udombana (2002), A Harmony or a Cacophony? The Music of Integration in the African Union Treaty and the New Partnership for Africa's Development, 13 Ind. Int'l \& Comp. L. Rev., p. 187.

${ }^{33}$ UNECA supra note 1, p 15. However, there are also evidences showing that regional integration could lead to tension between countries and ultimately to conflict. The tensions in the East African Community-and ultimately conflict between Tanzania and Uganda-all involved bitterness about large income transfers and growing divergence in incomes from common external tariffs. Ibid. 
participating in regional integration mechanisms. ${ }^{34}$ Integration will help the member countries to enhance their bargaining power and achieve more favourable trade terms during trade negotiations.

\section{Regional Integration in Africa}

Many regional integration schemes have been introduced in Africa in the past years. These integration efforts have been introduced both at the continental and sub-regional levels. Before delving into these integration efforts, it is worth looking into the prevailing economic and political conditions of the continent.

\subsection{Prevailing economic and political condition in the continent}

The African continent is characterized with poverty, food insecurity and high political instability. Most African countries are small with the majority of people living below poverty line. "Low incomes and widespread poverty reflect the weak production structures and low productivity of many African economies" ${ }^{35}$ The region's declining share in global production and trade shows how much the continent is marginalized in the global economy. African countries predominantly produce and export agricultural and other primary products to the global market and many of these economies suffer from lack of diversity in production and exports. ${ }^{36}$

In 2008, Sub Saharan Africa's share of $1.7 \%$ of world output and $1.9 \%$ of exports were higher than the $1.1 \%$ and $1.3 \%$ shares at the end of the $1990 \mathrm{~s}^{37}$; the increase in export is explained by the increase in the price of primary commodities worldwide. ${ }^{38}$ Though the change is significant, this growth was reversed in 2008/09 as a result of a decline of world commodity market in the wake of global financial and economic crisis without bringing any meaningful change in the economic circumstances of the population. ${ }^{39}$ This number, however, has improved in more recent years. In 2012, for example,

${ }^{34}$ Peter Draper and Mzukisis Qobo (2009), Multilateralizing Regionalism: Case

Study of African Regionalism, in Baldwin and Lows (eds.), Multilateralizing Regionalism: Challenges for the Global Trading System, Cambridge University Press, p. 405.

${ }^{35}$ UNECA supra note 1, p. 17.

36 Id., p. 20.

${ }^{37}$ McCarty, supra note 26, p. 352.

${ }^{38}$ WTO (2011), World Trade Report 2011: The WTO and Preferential Trade Agreements: From Co Existence to Coherence, Geneva, p. 23.

39 McCarty, supra note 26, p. 352. 
African merchandise exports amounted to $3.5 \%$ of world exports; though it was mainly dominated by fuel and mining products, accounting for $69.5 \%$ of total exports. ${ }^{40}$ The trade pattern, which is dictated by the types of items traded, also indicate that not much has changed since the earlier times. Europe remained Africa's major export destination of manufactured goods (40.3\% in 2012, down from 52\% in 2005) while Asia and North America accounted for $11.5 \%$ and $8.5 \%$ of African exports respectively. ${ }^{41}$

During the same period, the level of intra-regional trade has remained low. Despite the long history of regional integration efforts in the continent, the level of intra-Africa trade remains low in comparison with intraregional trade in other regions, both developed and developing. ${ }^{42}$ Intra-Africa trade is estimated to account for only around $12.8 \%$, whereas the level of trade with other parts of the world, i.e., Europe, Asia and North America is very high. ${ }^{43}$ Although some argue that these figures do not account for informal trade, which is very large in Africa, ${ }^{44}$ trade experts are of the view that even if allowance is made for this unrecorded informal cross border trade, the total level of intra-Africa trade is not likely to be more than $20 \%$, which is still lower. ${ }^{45}$ One development in this regard is the improvement in intra-trade between the Regional Economic Communities. A report by UNECA indicates that on an individual REC-by REC basis, intra-REC trade has been increasing in some RECs, such as COMESA and EAC. ${ }^{46}$

${ }^{40}$ AfDB, OECD and UNDP (2014), African Economic Outlook 2014: Global Value Chains and Africa's Industrialization, p. 75.

${ }^{41}$ Ibid. Major destinations for fuel and mineral exports were Europe (38.7\%), Asia (29.8\% and up from 15.7\% in 2005), and North America (14\% down from $28 \%$ in 2005), indicating that both traditional and emerging markets are crucial. Ibid.

42 UNCTAD (2009), Economic Development in Africa Report 2009: Strengthening Regional Economic Integration for Africa's Development, (United Nations Publication, Geneva), p 20. The average intraregional trade (export) during 20042006 for developing America was 18.5\% and 45.5\% for developing Asia while the figure for Africa was 8.7\%. Id., p. 21.

${ }^{43}$ See for example, AfDB, OECD and UNDP supra note 40, p. 75.

${ }^{44}$ Ibid.

${ }^{45}$ Meeting of the Committee of Experts of the $6^{\text {th }}$ Joint Annual Meetings of the ECA Conference of African Ministers of Finance, Planning and Economic Development and AU Conference of Ministers of Economy and Finance, held in Abidjan, Cote d'Ivoire, (21-24 March 2013), E/ECA/COE/32/3 AU/CAMEF/EXP/3(VIII), paragraph 3.

${ }^{46}$ United Nation Economic and Social Council, Economic Commission for Africa, Report on Africa's Regional Integration Agenda, Eighth Session of the 
The continent's economy is highly fragmented into small and poor countries. The sub Saharan Africa region has a population of 819 million but has a comparatively small level of economic activity which is further fragmented into 47 countries, the majority of which are classified as Least Developed Countries. ${ }^{47}$ For instance in 2008, 12 states among sub Saharan African (SSA) countries 'had populations of less than 2 million [each] while 20 had a gross domestic product (GDP) of less than US\$5 billion, of which no fewer than seven had a GDP of less than US\$1 billion - indeed tiny economies. ${ }^{48}$ Apart from the fact that many of the economies in SSA are small, the countries in the region are landlocked, and this negatively affects trade among these countries and with the outside world. As noted by McCarty, these small and underdeveloped economies face extreme difficulties in crossing the threshold to sustainable, diversified development through strategies that focus on domestic and foreign markets resulting in the marginalization of the continent. ${ }^{49}$

Many of the countries in the continent have inadequate infrastructure, weak institutions and political instability. Cross-border and civil conflicts or unrest remain a tragic reality in different parts of Africa. Many countries in the continent rely on agriculture as the main economic activity and source of income. Political instability and conflict impede agricultural production and productivity. Political instability and war, apart from negatively impacting agricultural production and productivity, destroy physical and human resources and cause social disorder which increases the cost of doing business. ${ }^{50}$ Ultimately, this adversely affects the growth and development of the country and food security of its inhabitants.

Food insecurity is one of the challenges encountered by many African counties. Studies show that, of the 39 countries worldwide that faced food emergencies at the beginning of 2003, 25 were found in Africa. ${ }^{51}$ Recent figures also depict a similar story. Political instability and war, lack of

Committee on Trade, Regional Cooperation and Integration, (6-8 February 2013), Addis Ababa, E/ECA/CTRCI/8/1, p. 6.

47 Colin McCarty (2010), Reconsidering Regional Integration in Sub Saharan

Africa, in Supporting Regional Integration in East and Southern Africa: A

Review of Select Issues, TRALAC, p. 2.

48 McCarty, supra note 26, p. 353.

49 McCarty, supra note 47, p. 3.

${ }^{50}$ UNECA supra note 1, p. 20.

51 Jenny Clover (2003), Food Security in Sub-Saharan Africa, 12 African Security Review, p. 6. 
appropriate policies and HIV and AIDS pandemic are considered as the main reasons for people in the continent to go hungry. The recent Ebola outbreak in Western African countries is also predicted to have a negative impact on the economic growth of countries affected by the outbreak, in particular, unless it is controlled as soon as possible. A study conducted by the UNECA at the end of 2014 indicated that the Ebola crisis is influencing investment and capital flows to these countries. ${ }^{52}$ However, the study indicates that the effect of the disease is negligible on the growth and development prospects of the continent. ${ }^{53}$

In general, although there are recorded improvements in recent years, Africa is still left far behind in the race towards economic growth and development. It is clear that there is a need to alleviate economic development to the region. In this regard, though regional economic integration is not a remedy, many agree that an appropriate development approach needs to incorporate integration, more emphasis being given to the process of regional integration which is adapted to the economic circumstance of the continent. ${ }^{54}$ It is with the view of addressing this development need of the continent that various regional integration initiatives have been witnessed in Africa.

\subsection{Continental wide movement towards regional integration}

More than half of current world trade occurs within trading blocks, and nearly every country in the world is a member of one or more regional integration agreements. ${ }^{55}$ The situation is no different for Africa as the continent is going through different waves of regionalism.

As Alemayehu \& Haile duly observed, 'regional integration initiatives in Africa have a long history, dating back to the establishment of the South African Customs Union (SACU) in 1910 and the East African Community

52 _UNECA (December, 2014), Socio-Economic Impacts of the Ebola Virus Disease on Africa, p. 5.

53 A simulation based on a 'bad scenario', where all three affected countries record zero growth in 2014 and 2015 suggest that the growth effect for these two years for west Africa will be only -0.19 and -0.15 percentage points, and for Africa as a whole a negligible -0.05 and 0.04 percentage points. Id., p. 28.

${ }^{54}$ McCarty Supra note 26, p. 352.

55 Maurice and Hoekman (2002), Benefiting from Regional Integration, in Development, Trade and the WTO, Washington DC, The World Bank, p. 548. 
(EAC) in $1919 .{ }^{56}$ Since then, a number of regional arrangements have been formed in the continent. In addition to agreements at a regional level, attempts have also been underway to create economic cooperation (and ultimately meaningful economic integration) among African countries at a continental level. ${ }^{57}$ This was first seen in the adoption of the Charter of the Organization of African Unity (OAU) and its establishment.

The OAU Charter, adopted by the heads of states and Governments in Africa in 1963, entrenched the fundamental objective of regional solidarity and cooperation for development. ${ }^{58}$ The OAU had undertaken different initiatives to integrate the Africa region for the promotion of economic and social development. In this regard, various regional and intergovernmental meetings were held which resulted in the adoption of various treaties, declarations and plan of actions. ${ }^{59}$

The continental wide regional integration in Africa was given greater emphasis after the 1979 meeting of the different African leaders at Monrovia. This meeting was the result of a colloquium convened jointly by the Economic Commission for Africa (ECA) and the OAU on 'Perspectives of Development and Economic Growth in Africa up to the Year 2000'. This was a pursuit which followed series of declarations by the UN, since the declaration of the 1960s, as the 'United Nations Development Decade'. ${ }^{60}$

In the 1979 Monrovia Declaration, African states committed themselves to the promotion of economic and social development and integration of their economies with a view to achieving self sufficiency and to the promotion of economic integration of Africa. ${ }^{61}$ The integration movement in Africa was taken one step further with the adoption of the Lagos Plan of Action for the economic Recovery of Africa (LPA) and the Final Act of Lagos in 1980. As described by Udombana, the LPA was the blueprint for

\footnotetext{
56 Alemayehu Geda and Haile Kebret (November 2007), 'Regional Economic Integration in Africa: A Review of Problems and Prospects with a Case Study of COMESA', 17 Journal of African Economies 3, p. 358.

${ }^{57}$ Ibid.

${ }^{58}$ OAU Charter, preamble paragraphs 3, 4, 7, 10, arts. II(1)(a)- (b), (e). Also see Dejo Olowu (2003), Regional Integration, Development and The African Union Agenda: Challenges, Gaps and Opportunities, 13 Transnational Law and Contemporary Problems, p. 217.

59 Ibid.

${ }^{60}$ Udombana, supra note 32, p. 194.

${ }^{61}$ See Paragraph 1 of AHG/ST.3(XVI)Rev.1, adopted by the Assembly of states and Government of the OAU adopted in July 1979 in Monrovia, Liberia.
} 
real economic independence in Africa as it aimed at self reliance, self sustaining development and economic growth of African countries. ${ }^{62}$

The essence of the LPA was the establishment of an African common market by the year 2000 which was to be achieved in phases, namely the formation of a Free Trade Area, then a formalized Common Market, and finally a Pan African economic union. ${ }^{63}$ It was envisaged that the different regional arrangements will be used as a building block for the formation of a large economic union. However, progress was slow on the implementation of the LPA and by the end of the 1980s, almost none of the targets set out by the LPA for a gradual establishment of an African Common Market were achieved.

In 1991African Heads of States signed the Treaty Establishing African Economic Community (AEC) in Abuja, Nigeria. ${ }^{64}$ Paragraph 3(V) of the preamble to the LPA reflects the view of the signatories that the Plan will pave the way for the formation of an African common market leading to the AEC. ${ }^{65}$ In this regard, the Abuja treaty seems to be a continuation of the integration effort started under the LPA. The treaty which entered into force in 1994, envisaged a strong pan-African economic community built on the ramparts of the existing sub regional bodies. ${ }^{66}$ The treaty aims at establishing economic integration by strengthening the existing regional blocks. The AEC treaty had set 2028 as a new date for attaining a Pan African economic community comprising fifty-three states and some 600 million people. ${ }^{67}$ This is intended to be achieved over a period of thirty four years using six levels or stages of integration. ${ }^{68}$

${ }^{62}$ Udombana, supra note 32, p. 194.

${ }^{63}$ Lagos Plan of Action for the Economic development of Africa 1980-2000 (LPA), Paragraph $3 / \mathrm{V}$ of the Preamble.

64 Olowu, Supra note 58, p. 217.

65 Preamble of the LPA.

${ }^{66}$ Craig Jackson (2003), The African Union and the New Pan-Africanism: Rushing to Organize or a Timely Shift: Constitutional Structure and Governance

Strategies for Economic Integration in Africa and Europe, 13 Transnational Law and Contemporary Problems, p. 145.

${ }^{67}$ See Article 4/1 and 4/2 of the Treaty Establishing the African Economic Community, adopted June 3, 1991 (entry in to force May 11, 1994), available at $<$ http://www.uneca.org/itca/ariportal/abuja.htm $>$ [accessed on December 15, 2014] (Abuja Treaty) and Olowu supra note 58, pp. 217-218.

${ }^{68}$ Id., p. 229. 
The first three stages of the integration process are expected to be achieved by the RECs while the remaining stages relate to integration at continental level. The first stage requires the strengthening of existing RECs over a period of five years from the date of entry into force of the treaty. The second stage, which involves coordination and harmonization activities and progressive elimination of tariff and non tariff barriers in the existing RECs, is to be achieved over a period of eight years, bringing the timeline to 2007. By 2017, all regional groupings are expected to launch Free Trade Area and Customs Union.

By 2019, a continental customs union is to be established through coordination and harmonization of tariff and non tariff systems among the various RECs and by means of adopting a common external tariff. Within four years after the establishment of the customs union, i.e., by 2023 an African Common Market will be established through the adoption of common policy in various areas, harmonization of monetary, financial and fiscal policies and applying the principles for free movement of persons. At the sixth and final stage, which is to be achieved by 2028, a continental Economic and Monetary Union will be established. ${ }^{69}$ When we look into the progress so far made, we observe mixed results across the eight AU recognized RECs. ${ }^{70}$ While COMESA, EAC, ECCAS, ECOWAS and SADC are at stage three as they have reached FTA status and launched customs union (CU) programs, IGAD and CEN-SAD are at stage two. ${ }^{71}$

Cognizant of the low level of intra-Africa trade and slow progress towards achieving the stages of integration, a decision was made by the AU Heads of States and Governments to fast track the establishment of a Pan African Continental Free Trade Area (CFTA). To this end, the $18^{\text {th }}$ AU summit focused on the theme "Boosting Intra-African Trade", and one of the important outcomes of the summit included its decision on Action Plan for boosting intra Africa trade in the short, medium and long term and on the establishment of the CFTA by the indicative date of $2017 .^{72}$ The upcoming January 2015 Summit of AU Heads of State and Government is expected to reaffirm the commitment to launch the CFTA negotiations in June 2015 and

${ }^{69}$ See article 6/2/a-f of the Abuja Treaty for the stages of integration.

${ }^{70}$ See infra note 74.

${ }^{71}$ Report on Africa's Regional Integration Agenda, Eighth Session of the Committee on Trade, Regional Cooperation and Integration, (6-8 February 2013), Addis Ababa, E/ECA/CTRCI/8/1, paragraph 7.

${ }^{72}$ Id., paragraph 21. 
give mandate to the Ministers of Trade to meet and finalize preparations for the launch. ${ }^{73}$

\subsection{Regional Economic Communities (RECs)}

The continental wide efforts at integration were taking place in parallel with the formation of regional economic communities in different parts of the continent. Since the formation of the first customs union, SACU, in 1910, several RECs have been established by African countries. From among these several RECs only eight have been given recognition by the Assembly of Heads of State and Government of the African Union while suspending the recognition of new RECs. The eight RECs recognized by the Assembly are ECOWAS, COMESA, EAC, ECCAS, SADC, IGAD, AMU and CENSAD. ${ }^{74}$ The oldest customs union in the world, SACU, the Economic and Monetary Union of West Africa (UEMOA) and the Customs and Economic Union of Central Africa (UDEAC) are among the RECs which are not given recognition by the AU.

These regional blocs or economic groupings have the common goals of economic transformation and development, implicitly including eradication or reduction of poverty in the process. The regional groupings, with the exception of COMESA ${ }^{75}$, were in existence and operating at the time of the signing of the Abuja treaty. The Abuja treaty aspires to create an African Economic Community, and proposes to use the existing RECs as building blocks of the Community. It is with this in mind that the AU Assembly of Heads of State and Government suspended, until further notice, the recognition of new RECs. The following paragraphs highlight the objectives and mandates of some RECs.

The Economic Community of West African States (ECOWAS) was established in 1975 based on the Treaty of Lagos. ${ }^{76}$ The objective of ECOWAS, as illustrated under article 3 of the 1993 revised treaty, is:

${ }^{73}$ The Assembly of the Union, $24^{\text {th }}$ Ordinary Session, is expected to be held on 30 31 January 2015.

${ }^{74}$ African Union, Decision on the Moratorium on the Recognition of Regional Economic Communities, Assembly/AU/Dec.112(VII), 2006.

${ }^{75}$ COMESA came in to existence in 1994 by replacing the Preferential Trade Area for Eastern and Southern Africa, which was established in 1981.

${ }^{76}$ James Thuo Gathii, (2011), African Regional Trade Agreements as Legal Regimes, Cambridge University Press, p. 144. 
to promote cooperation and integration, leading to the establishment of an economic union ... to raise the living standards of its people, and to maintain and enhance economic stability, foster relations among member states and contribute to the progress and development of the African continent.

The objective of ECOWAS extends to cooperation in almost all the sectors of the respective economies of the member states. The ECOWAS treaty aims to achieve economic integration through the harmonization and coordination of national policies and the promotion of integration programs. ${ }^{77}$ Although ECOWAS was formed with the purpose of economic integration and cooperation, it has (in the past decade) assumed a more active role in the management of regional conflicts and humanitarian crisis $;{ }^{78}$ and its mandate has been extended accordingly by the revised treaty of 1993. Several efforts have also been undertaken by member states of ECOWAS to establish a common currency amongst themselves as the eventual goal of the economic cooperation was to establish monetary union in the region. ${ }^{79}$

In the Eastern Africa region, COMESA was established in 1994 by replacing the Preferential Trade Area for East and Southern Africa. COMESA is one of the largest trading blocks in Africa comprising 19 countries. ${ }^{80}$ The COMESA region covers countries mostly from Eastern and Southern Africa, and includes Egypt from the North and Angola and Democratic Republic of Congo from the Central._COMESA was established with the objectives of:

attaining sustainable growth and development of its member states; promoting a more balanced and harmonious development of its production and marketing structures; promoting joint development in all fields of economic activity, and the joint adoption of macroeconomic policies and programs to raise the standard of living of its

${ }^{77}$ Ibid.

${ }^{78}$ Udombana supra note 32, p. 200 The Economic Community of West African States Monitoring Group was established in 1990 to intervene in the civil war in Liberia and was later deployed to quell unrest in Sierra Leon and Guinea-Bissau. See Erin Carr, (2010), Regional Integration in West Africa: The Evolving Role of the Economic Community of West African States (ECOWAS), 5 International Affairs Journal, p. 77.

${ }^{79}$ See article 3/2/e of the ECOWAS Treaty on the objective of creating monetary union.

${ }^{80}$ See $<$ www.comesa.int $>$ for list of member countries. 
peoples; and fostering closer relations among its member states, cooperate in the creation of an enabling environment for foreign and domestic investment, cooperate in the promotion of peace and security and stability among members, ... contributing towards the establishment, progress and the realization of the objectives of the African Economic Community. ${ }^{81}$

In order to achieve these aims, the members have undertaken to establish a customs union, abolish all non-tariff barriers to trade among themselves, establish a common external tariff and co-operate in customs procedures and activities. ${ }^{82}$ Accordingly, the COMESA Free Trade Area was achieved at the end of October 2000 when nine of the member states eliminated their tariffs on COMESA originating products in accordance with the tariff reduction schedule adopted in $1992 .{ }^{83}$ The COMESA Customs Union was also launched at the $13^{\text {th }}$ Summit of the COMESA Heads of States and Governments in June 2010.

Another regional grouping within the Eastern Africa region is the East African Community (EAC). The East African Community (EAC) was established with the signing of the establishment treaty in 1999, which entered in to force in 2000, by Kenya, Tanzania and Uganda. Later on, the membership to EAC increased to five with the entry of Burundi and Rwanda in 2007. The Protocol for the establishment of the East African Customs Union was signed in March 2004 and entered into force in 2005. After five years in 2010, the Customs Union entered into force. At the $11^{\text {th }}$ Ordinary Summit held in November 2009, the EAC Heads of States signed and approved the EAC Common Market Protocol which was ratified by all five members by April $2010 .^{84}$ The Protocol came into force together with the annexes and schedules in July 2010, making the EAC the most advanced RTA (Regional Trade Agreement) in the continent. ${ }^{85}$

81 Article 3 of the COMESA Treaty.

${ }^{82}$ Article 4 of the COMESA Treaty.

${ }^{83}$ The nine countries are Djibouti, Egypt, Kenya, Madagascar, Malawi, Mauritius, Sudan, Zambia and Zimbabwe. See Overview of COMESA, <www.comesa.int $>$ [accessed on November 15, 2014]. Later Rwanda and Burundi Joined the Free trade agreement, bringing the total number of countries to the FTA 11.

${ }^{84}$ Teresa Thorp (2012), The Rule of Law and the Implementation of Economic Acquis Communautaire in Sub Saharan Africa: Legal Challenges for the East African Community, European Year Book of International Economic Law, p. 486.

${ }^{85}$ Gathii, supra note 76, p. 188. 
The REC recognized by AU in the Southern Africa region is Southern Africa Development Community (SADC). It replaced the former Southern African Development Coordination Conference (SADCC), and came to existence in 1992. Currently SADC has 15 member states. ${ }^{86}$ SADC is established with the objectives of, among others:

promoting sustainable and equitable economic growth and socioeconomic development, enhance the standard and quality of life of the people of Southern Africa and support the socially disadvantaged through regional integration; promote common political values, systems and other shared values, consolidate, defend and maintain democracy, peace, security and stability; promote self-sustaining development on the basis of collective self-reliance, and the interdependence of Member States... ${ }^{87}$

The SADC also aims at alleviating poverty through regional integration as regional integration increases economies of scale and makes more resources available which will ultimately provide a more propitious environment to address persisting social inequality and poverty. ${ }^{88}$ SADC has a specific protocol on trade which resulted in the launching of a free trade area in 2008.

\section{Challenges in the Pursuits of Africa's Economic Integration}

Although various RECs have been formed in Africa, these initiatives did not deliver much to uplift the economic conditions of the members and ensure sustainable growth and development. ${ }^{89}$ Moreover, the proportion of intraregional trade to total trade remains much lower in African RECs compared to RECs in other regions. ${ }^{90}$ Various reasons have been pointed out for the failure of African RECs to deliver their mission. The first factor relates to the gap between the agreements concluded and their implementation. The record of implementation of treaties, protocols and

\footnotetext{
${ }^{86}$ This number includes South Africa, which joins the arrangement in 1994. See $<$ www.sadc.int $>$.

${ }^{87}$ Article 5 of the SADC Treaty.

${ }^{88}$ Luwam Dirar (2010), Common Market for Eastern and Southern African Countries: Multiplicity of Membership Issues and Choices, 18 Af.J.I.C.L 2, p. 225.

${ }^{89}$ UNCTAD, supra note 42, p. 14.

90 Ibid.
} 
decisions is far from satisfactory. ${ }^{91}$ This can be attributed to the adoption of unrealistic and unfeasible dates for implementation and lack of institutional architecture of the regional economic communities that has the power, authority and resource to enforce decisions and monitor the implementation of programs. ${ }^{92}$ As Gathii observes, African regional arrangements are different from their European counterparts as they are not based on an approach that focuses on whether countries are complying point by point with the treaty. ${ }^{93}$ He notes that regionalization grows not only out of formal institutions but independently of them as well $;{ }^{94}$ implying that non implementation of treaties is one aspect of the flexible nature of integration in the continent.

A second problem, which is related to the first, is the existence of multiple, overlapping and often conflicting regional integration arrangements within the same region. ${ }^{95}$ Many African countries belong to more than one REC. Among the $53^{96}$ countries in Africa, 27 are members of two regional groupings, 18 belong to three, and one country is a member of four. ${ }^{97}$ This makes implementation difficult as it imposes a heavy burden on the limited administrative resources available in the member countries. Multiple membership reflects the desire of countries to pick and choose various options offered by competing regional trading arrangements. ${ }^{98}$

As the different regional arrangements have objectives other than trade which are different from one REC to another and appealing to some but not to all concerned countries, the countries tend to join all or more than one. ${ }^{99}$ However, this tendency of countries to join more than one REC poses challenge on the member countries to fulfill their obligation arising from the different treaties and threatens integration in the region. Multiplicity of membership adds a burden on the financial obligations and policy decisions

91 Marcelo Olarreaga and Manuel de la Rocha (2003), Multilateralism and

Regionalism: Trade Opportunities for sub-Saharan Africa, 38 Africa spectrum 1, p. 103.

${ }^{92}$ UNECA supra note 1, p. 59.

93 Gathii supra note 76, p. 11.

94 Ibid.

95 Olarreaga and Rocha, Supra note 91, p. 104.

${ }^{96}$ This number (in UNCTAD, 2009, supra note 42) does not include Southern Sudan.

${ }^{97}$ UNCTAD supra note 42, p. 11.

98 Ghatti supra note 76, p. 67.

${ }^{99}$ See the discussion by Ghatti (id.,) pp. 68-70. 
making of the members. A country that belongs to two or more RECS will face multiple financial obligations, and at the same time must cope with different meetings, policy decisions, and harmonization of policies, procedures, and schedules. ${ }^{100}$

The tariff rates and rules of origin will also be issues while dealing with multiple memberships. For instance, COMESA, SADC and EAC share similar aims of creating a customs union, and the EAC Common Market has already been implemented. In Customs Union, there will be a common external tariff decided at the community level, and not by individual countries. Hence, countries that belong to more than one REC encounter difficulties in deciding the common external tariff to be imposed.

Similar problems can be observed with regard to rules of origin. For example, the rules of origin of COMESA and EAC are more or less similar as they are based on value added rule of $35 \%$ for local content or customs, insurance, and freight (CIF). ${ }^{101}$ Their major difference is that COMESA has an exception for "goods of particular importance" requiring only a minimum of $25 \%$ of ex-factory costs of imported materials, while this exception does not exist in EAC. On the other hand, the SADC rules of origin are markedly different as they are product-specific and are adapted specifically to the particular production process used in an industry. ${ }^{102}$ The question then becomes as to which rule of origin is applied by a country that has membership in both SADC and either EAC or COMESA?

Such countries have to seriously reconsider their membership as it is impossible to have two different common external tariffs. Moreover, there is a possibility for "partially conflicting membership obligations, different strategies and internal liberalization objectives, inconsistent external liberalization goals, different timetables and phase-in periods, different coverage, and different and conflicting rules and administrative procedures"103 which will ultimately hinder the integration process. In this regard, the steps taken by Angola, Lesotho, Mozambique and Tanzania in

\footnotetext{
100 Alemayehu and Haile supra note 56, p. 376.

${ }^{101}$ See the COMESA protocol on rules of origin.

102 Gerhard Erasmus and Trudi Hartzenberg (2014), The Tripartite Free Trade Area: what will it be, and How will it Come About?, in C. Herrmann, M. Krajewski and J. P. Terhechte (eds), European Yearbook of International Economic Law, p. 351.

103 Hansohm, supra note 22. p. 8.
} 
withdrawing from their membership of COMESA to remain in SADC should be appreciated. ${ }^{104}$

A related problem to multiplicity of organizations is the uncertainty it creates in the minds of individual traders as a result of the difference in the legal jurisprudence generated in the different RECs. The RECs have their own legal personality; they are legal entities and as such generate their own jurisprudence. ${ }^{105}$ Multiplicity of membership subjects individuals to numerous legal regimes inviting for forum shopping and generating conflicting results. This will again create a problem in the enforcement of judgments entered by tribunals that are created by the RECs. The dispute resolution mechanism set up by COMESA and SADC, whose members have overlapping memberships best explains the problem.

Article 31 of the COMESA treaty provides that the decisions of the COMESA court, subject to certain provisions relating to review, are "final and conclusive and not open to appeal." A similar provision is contained under article 16 of the SADC treaty which provides that the decisions of the Tribunal ${ }^{106}$ shall be final and binding. If, for example, the COMESA court issues a binding, non appealable judgment which is contrary to the binding and non appealable decision of the SADC tribunal concerning the same issue in respect of same parties, reconciling the concurrently binding decisions becomes very difficult thereby adversely affecting intraregional trade. As noted by Kiplagat, a stalemate produced by the multiplicity of jurisdictions may chill cross border trade as private traders need some

${ }^{104}$ David A. Lynch (2010), Trade and Globalization: An Introduction to Regional Trade Agreements, Rowman \& Littlefield Publishers Inc, p. 67.

${ }^{105}$ P Kenneth Kiplagat (1995), Jurisdictional Uncertainties and Integration Processes in Africa: The Need for Harmony, 4 Tulane Journal of International \& Comparative Law, p. 50.

106 The SADC tribunal has been suspended since 2010. The reason for its suspension was the ruling it made against Zimbabwe in 2008 in a dispute involving the expropriation of private land without compensation in which Zimbabwe was found to be in violation of the SADC Treaty. The decision, which was in favor of a private applicant, was not implemented. And the SADC Summit, to which the matter was referred to, decided to develop a new Protocol for the tribunal and it did not renew the terms of the serving judges, effectively suspending the tribunal. A new Protocol was adopted in the August 2014 SADC Summit which, if it obtains sufficient ratification, will set up a new Tribunal.

See Gerhard Erasmus (January 2012), What has Happened to the protection of rights in SADC? TRALAC Trade Brief No. S12TB01/2012 and $<$ www.tralac.org $>$ for new developments on SADC tribunal. 
degree of assurance that there are effective mechanisms for the resolution of cross border disputes before they engage in any cross border trade. ${ }^{107}$

The existence of multiple RECs poses some difficulty on AU's efforts of integration on the continental level. The Abuja treaty uses existing RECs as a stepping stone for the formation of the African Economic Community. In this regard, one concern pertains to the relationship between the different RECs and the AEC (when it is formed). In an effort to provide answer for this, the AU adopted a Protocol on the Relations between the African union and the Regional Economic Communities [Protocol on Relations] in 2007; ${ }^{108}$ and the Abuja treaty itself also tries to address this concern. Accordingly, article 88 of the Abuja treaty envisions the formation of the African Economic Community through the coordination, harmonization and progressive integration of the activities of the various RECs.

The coordination and harmonization amongst these RECs is eventually expected to lead to their absorption upon the formation of the African economic community. ${ }^{109}$ This plan embodied in the Protocol raises a number of legal issues in view of the fact that it is the individual African countries and not the RECs that are parties to the Abuja treaty. One important issue will be identifying the legal basis for assuming that the RECs, which have their own legal personality, will merge and form the African Economic Community. ${ }^{110}$ The RECs, with the exception of COMESA, do not anticipate their merger or absorption into the AEC. Article 178 of the COMESA treaty recognizes that the final objective of the Common Market is to contribute to the implementation of the provisions of the Abuja treaty and to that end members will:

... convert the Common Market or its successor, at a time to be agreed upon between the Common Market or its successor and the African Economic Community, into an organic entity of the African Economic Community.

Once the Economic Community is formed, COMESA, since it forms an organic entity of the Community, will cease to exist. In this regard, the

\footnotetext{
107 Kiplagat, supra note 105, p. 53.

108 Protocol on Relations, available at $<$ www.african-union.int $>$

109 Article5(1)(d) of the Protocol on Relations.

110 Richard Frimong Oppong, (2010), The African Union, The African Economic Community and Africa's Regional Economic Communities: Untangling a Complex web'. 18 Af.J.I.C.L 1, p. 94.
} 
Authority (composed of the Heads of State and Government) ${ }^{111}$ is given the mandate to terminate the operation of the Common Market upon recommendation of the Council of Ministers. ${ }^{112}$ Here, we can see that a legal mandate exists for the termination of COMESA if that is what is needed after the formation of the African Economic Community. ${ }^{113}$ Unlike the COMESA treaty, the remaining seven RECs recognized as building blocks of the African Economic Community do not contain similar provisions. In the absence of such provision, it is very difficult to assume their merger. There is also a concern relating to the relationship between the African Economic Community and the other RECS in the region which are not recognized as building blocks of the AEC.

Other explanations for the impediment of regionalism in Africa relate to initial conditions like the lack of complementarities among regional partners in goods and factors of production. ${ }^{114}$ The economies of African countries are mainly dominated by the agriculture sector, resulting in the noncomplimentarity of the goods traded among these countries. In recent years, this trend has slightly improved as intra African exports are somewhat getting diversified. Although the intra Africa exports are still dominated by primary products, manufactured and intermediate goods appear to be gaining significance in trade within the regional groups, which, however, is characterized by a small number of lightly processed exports. ${ }^{115}$

Another major challenge in the African integration effort is that of infrastructure. Problems with roads, rail, ports, air transport, energy, telecommunications and other infrastructure are cited by the business community as one of the chief constraints to economic growth and integration in Africa. ${ }^{116}$ Inadequacy of roads that connect African countries poses a challenge in boosting cross border trade. The length of paved roads as percent of total roads in Africa is about five times less than that of high income OECD (Organization of Economic Cooperation and Development) countries. ${ }^{17}$ A related challenge is that of transportation. The transport

\footnotetext{
111 Article 7 of the COMESA Treaty.

112 Article 192 of COMESA Treaty.

113 Oppong, supra note 110, p. 194.

${ }^{114}$ UNCTAD, supra note 42, p. 14.

115 AfDB, OECD and UNDP supra note 40, p. 77.

${ }^{116}$ Charles Abuka, (2005), Infrastructure, Regional Integration and Growth in Africa, in Africa in the World Economy-The National, Regional and International Challenges, Fondad, The Hague, p. 122.

${ }^{117}$ ECA, UNOSOC E/ECA/CTRCI/8/1, paragraph 25.
} 
sector in the continent is characterized by fragmentation, inadequate capacity, and poor performance as road and rail network is sparse and many of its sea ports and airports are in need of refurbishment and expansion. ${ }^{118}$

Energy infrastructure is also an important element in integration. Many African countries are characterized by lack of sufficient energy infrastructure. It is well recognized by the authorities in the continent that without adequate energy, Africa cannot effectively trade among its member countries or develop sustainable industries, inhibiting its ability to improve the livelihoods of its population. ${ }^{119}$

There is also vast economic disparity between the different African countries making it difficult to engage in equal level of openness, ${ }^{120}$ and may even cause delay in the adoption of decisions toward further integration. An example here is the 1996 draft SADC protocol on free movement of people. The draft protocol had the objectives of phasing in, over a period of 10 years, the free movement of citizens of SADC member states between and within countries in the region and to regulate the movement of citizens of non SADC citizens into and within the region. ${ }^{121}$ However, the draft Protocol was abandoned as a result of the insistence of South Africa, Botswana and Namibia against its adoption. ${ }^{122}$

While there is no agreed regional legal framework on movement of persons within the SADC region, the economic dominance of South Africa made it an attractive destination for migrant workers, mainly entering the country through illegal means. This again ignites another challenge as migrant workers are considered as 'taking away' local jobs making them susceptible to marginalization and, in worst case scenario, to attacks. One cannot forget the 2008 xenophobic attacks on migrant African workers in South Africa. The sad thing is, there is no guarantee that such attacks will not happen in the future. The integration effort is challenging as the economic disparity in 'marriage between unequals' renders win-win reciprocities and mutual benefits difficult. Under such settings of significant

\footnotetext{
${ }^{118}$ Id., paragraph 26.

${ }^{119}$ Id., Paragraph 27.

${ }^{120}$ Olwou, supra note 58, p. 240.

${ }^{121}$ Vincent Williams, In Pursuit of Regional Citizenship and Identity: The Free Movement of Persons in the Southern African Development Community, Policy: Issues and Actors, Vol. 19, No1, p. 7.

${ }^{122}$ Ibid. Another draft Protocol on the Facilitation of Movement of Persons was tabled as an alternative and approved by SADC in 2005, but has not entered into force as it has not secured the required ratification number.
} 
inequalities in economic performance and institutional competence, free movement of people encounters challenges even though it is one of the features of economic integration.

Yet another challenge is the fact that integration efforts in Africa have mainly been state-centric, confined to a narrow group of political leaders and technocrats. ${ }^{123}$ There is no or very minimal participation of the general public in discussing integration initiatives. Non-state actors that play key roles in the political economy of Africa are also given limited attention on the issue of integration. ${ }^{124}$ Decisions at the continental and regional levels are adopted with limited participation and discussion at the national level. Failure to disseminate decisions and protocols relating to regional integration issues to private actors and the general public in general, has contributed to hindering the integration process of the continent. ${ }^{125}$ This has also contributed to the limited progress in mainstreaming regional integration agreements and decisions adopted both at the regional and continental level into national development plans and strategies. Implementation of the decisions at national level remains limited and a number of countries are yet to fully integrate the decisions into their national development strategies. ${ }^{126}$ It is in view of this fact that AU summits usually emphasize the importance of involving various stakeholders. ${ }^{127}$

\section{The Way Forward}

It has been discussed that regional integration helps to pull resources together and facilitate investment by providing a wider and larger market. The availability of a wider market through integration of small fragmented markets is a requisite for the success of the integration. It follows that wider markets created by integration enhance the premium to be reaped and lower per unit cost of production. ${ }^{128}$ Although African countries have followed the footsteps of other continents, particularly the EU in pursuance of these benefits, it seems that the success achieved in other parts of the world on regional integration has eluded Africa.

\footnotetext{
123 Udombana, supra note 32, p. 203.

124 Ibid.

${ }^{125} \mathrm{E} / \mathrm{ECA} / \mathrm{CTRCI} / 8 / 1$, paragraph 33.

${ }^{126}$ Ibid

${ }^{127}$ For example, the Assembly of the Union, Eighteenth Ordinary Session 29-30 January 2012 (held in Addis Ababa) underlined the need to involve stakeholders in the course of integration pursuits.

${ }^{128}$ Kiplagat, supra note 107, p. 56.
} 
The regional trading blocs which were created to transform the African economy have failed to reap the benefits they planned to. But this does not mean that there are no success stories in African regional integration efforts. The ratification of the EAC Common Market protocol makes the EAC the most advanced REC in the continent. Some members of the REC have built closer ties as they have undertaken further integration commitments. Rwanda, Uganda and Kenya agreed to adopt a single EAC tourist visa in 2014 , and in effect, international visitors can move freely in these states. ${ }^{129}$ The countries have also agreed, with Burundi, on the future use of national identity cards as travel documents. ${ }^{130}$ The region is also investing in a standard gauge regional rail, roads, energy and port infrastructure aiming to strengthen links to the key ports of Mombasa and Dar es Salaam. ${ }^{131}$ In the western part of the continent, ECOWAS has introduced a common passport, though travel across the region remains challenging. ${ }^{132}$ It has also established national committees to address non-tariff barriers and started 'complaint desks' at borders. ${ }^{133}$ The establishment of the COMESA Competition Commission is another achievement in integration observed in the eastern part of the continent.

While these achievements in regional integration effort in the continent should be appreciated, various measures should also be taken to tackle the problems underlying integration efforts. Apart from the inadequate level of interest in African countries to implement treaties, their multiple memberships in the different RECs have made implementation on the national level an impossible task. Without absolute political commitment to implementing integration policies and programs at the national level, there can be little progress at the sub regional or regional levels. ${ }^{134}$ The problems resulting from multiple memberships and the legal foundation for the relationship between the African Economic Community and the RECs in Africa have to be reconsidered. As is reflected under article 3(1) of the Constitutive Act, one of the objectives of the AU is the coordination and harmonization of policies between existing RECs. However, the absence of monitoring and enforcement mechanism to ensure implementation of the letters of the different treaties impedes the AU from achieving this objective.

\footnotetext{
${ }^{129}$ AfDB, OECD and UNDP supra note 40, p. 79.

${ }^{130}$ Ibid.

${ }^{131}$ Ibid.

132 Id., p. 80.

${ }^{133}$ Ibid.

134 UNECA, supra note 1, p. 59.
} 
In this regard, the necessary mechanism must be put in motion for a dynamic cooperation with the RECs and the enhancement of intra and inter-regional trade. $^{135}$

The number of existing RECs and the multiplicity of their membership call for rationalization of the different RECs. The rationalization of the RECs must be seen in light of the objective of the Abuja treaty to establish the African Economic Community and needs to consider the difficulty of integrating all African countries, with different political and economic condition, at one time. The decision to fast track the launching of the continental FTA seems hasty in light of existing challenges of integration in the continent. The author is of the belief that it is rather desirable to strengthen the existing RECs and draw the road map in which these RECs can merge (two or three at a time). In this regard, the effort to establish the COMESA-EAC-SADC tripartite free trade area is a step forward in the right direction.

In October 2008, the heads of states and governments of the three RECs endorsed the harmonization agenda through the adoption of the Kampala Communiqué 2008. Accordingly, they agreed to establish a free trade area which entails the creation of a large single market with free movement of goods, services and business persons. ${ }^{136}$ Joint infrastructure development programs focusing on transport, information communication technology, energy and civil aviation are also included in the communiqué. Moreover, the development of common position on the Economic Partnership Agreement negotiations and other multilateral negotiations is envisaged in the Kampala Communiqué. ${ }^{137}$

Following the adoption of the Kampala Communiqué, negotiations on the EAC-COMESA-SADC Tripartite FTA was launched in June 2011 with the adoption of a Declaration and a set of Negotiating Principles. ${ }^{138}$ The Tripartite Free Trade Area, encompassing 26 States with a combined population of 625 million people and a Gross Domestic Product (GDP) of USD 1.2 trillion, will account for half of the membership of the African Union and $58 \%$ of the continent's GDP. ${ }^{139}$ Its immediate objective is to

\footnotetext{
135 Udombana, supra note 32, p. 222.

136 Final Communiqué of the COMESA-EAC-SADC Tripartite Summit of Heads of State and Government, paragraph 14/I, available at <www.comesa.int>

${ }^{137}$ Id., paragraph 14/V.

${ }^{138}$ Erasmus and Hartzenberg supra note 102, p. 345.

$139<$ http://www.comesa-eac-sadc-tripartite.org $>$.
} 
reduce the thickness of borders across the continent so as to raise interregional trade across the continent. ${ }^{140}$

The negotiations for the Tripartite Free Trade Area (TFTA) are being conducted in different phases: the preparatory phase, phase one and phase two. The preparatory phase ran from December 2011 to November 2012, and it mainly covered the exchange of all relevant information, including tariffs as well as trade data and measures. ${ }^{141}$ The first phase of the negotiation, which the three RECs are finalizing, covers primary FTA issues of tariff liberalization, rules of origin, customs procedures and simplification of customs documentation, and transit procedures among other issues. ${ }^{142}$ Parallel to the negotiation on these issues, a separate track of negotiation on the liberalization of movement of business persons is underway. The second phase of the negotiations will cover trade in services and other new generation trade issues such as investment, competition policy, and intellectual property rights. This phase will only commence after the completion of the first phase of the negotiations. ${ }^{143}$

Originally, it was planned to launch the TFTA in December 2014 at the Tripartite Summit of Heads of State and Government in Cairo, Egypt. However, it was delayed and rescheduled for the first quarter of 2015, according to a draft report of the senior official's meeting that preceded the December African Union Conference. ${ }^{144}$ It was latter indicated that the TFTA will be launched sometime mid $2015 .{ }^{145}$

${ }^{140}$ Jaime de Melo, (November 4, 2014), The Tripartite Free Trade Area: Is it the Way to Deepen Integration in Africa?, available at $<$ http://brookings.edu/blogs/africa-in-focus/posts/2014/11/04>.

${ }^{141}$ Bridges Africa, (23 August 2014), Good Progress in Tripartite FTA; Rules of Origin remain a Challenge, available at $<\mathrm{http}$ ://www.ictsd.org/bridgesnews/bridges-africa/news/good-progress-on-tripartite-fta-rules-of-origin-remaina-challenge>.

${ }^{142}$ Ibid, see also the Roadmap on Negotiation available at the TFTA website $<$ http://www.comesa-eac-sadc-tripartite.org $>$.

${ }^{143}$ Erasmus and Hartzenberg supra note 102, p. 346 see also the Road map on Negotiation .

${ }^{144}$ See Bridges Africa, (10 December 2014), <http://www.ictsd.org/bridgesnews/bridges-africa/news/african-union-encourages-concrete-action-as-regionaltrade>.

${ }^{145}$ These commitments are expected to be reiterated during the upcoming AU Summit. 
It is believed that the TFTA will narrow down the discrepancy among the RECs and overcome problems associated with overlapping membership. This can be achieved by, for example, addressing the challenge with regard to the difference in rules of origin (RoO) adopted by the three RECs. The TFTA could respond to this challenge. But for the TFTA to work, a new RoO framework needs to be developed that addresses preferential trade flows, and which can harmonize the rules of origin, because SADC's rules of origin, for example, differ substantially from the rules contained in the COMESA and EAC rules. ${ }^{146}$ In the course of the first phase of the negotiations, it was noted that rule of origin is among he core issues to be addressed. Whether the TFTA will bring a solution to this remains to be seen in the near future.

On the other hand, though the TFTA is an initiative which is meant to address the problem of overlapping membership, there is also the risk that it may rather reinforce the problem. Article 50 of the draft agreement provides that 'it [the Agreement] shall enter into force upon ratification by a simple majority of the Tripartite Member States that are party to this Agreement and Tripartite Member States undertake to do so timely. ${ }^{147}$ If some member States decide not to ratify the agreement, it will create more complications with regard to overlapping membership as this could mean that there will be four RECs, and those countries not joining will continue to trade with the other member states in terms of existing REC rule. ${ }^{148}$ Yet, we can remain optimistic and believe that the draft treaty will get sufficient ratification thereby enabling the TFTA to ultimately resolve the problem of multiple memberships.

Yet another option can be limiting membership of countries to only one REC. While the 2006 AU moratorium on the recognition of more RECs was an important step, limiting the membership of states to only one REC will be another important step to avoid all the challenges of multiple memberships. The adoption of a protocol on a 'one country one community membership' as one of the AU recognized principles on REC is essential. ${ }^{149}$ This will make countries to seriously think of their membership in different regional integration schemes before signing to one. In the meantime, devising a

\footnotetext{
${ }^{146}$ Eckart Naumann (2011), Tripartite FTA Rules of Origin: Reflections in the Status Quo and the Challenges ahead, in, Cape to Cairo: Making the Tripartite Free Trade Area Work, TRALAC, pp 257-258.

${ }^{147}$ See article $50 / 3$ of the draft TFTA agreement.

${ }^{148}$ Erasmus and Hartzenberg, supra note 102, p. 347.

149 Oppong, supra note 110, p. 97
} 
mechanism in which there will be exchange of information among the different RECs will allow the RECs to learn from each other. In this regard, the steps taken by COMESA, EAC and SADC are commendable. The EAC and COMESA have a memorandum of understanding to foster the harmonization of their policies and programs while COMESA and SADC have set up task forces to deal with common issues and invite each other to their policy and technical meetings. ${ }^{150}$

The different RECs should also revisit their treaties in light of the common vision of creating the African Economic Community. Apart from COMESA, the other seven RECs do not tell us what their fate will be following the establishment of the Community. Addressing this legal gap will enable the members to work together towards the establishment of the Community thereby avoiding any conflicting obligations.

The other challenge that African countries need to address is improving their peace, stability, political environment and governance so as to create a suitable operating environment for business. Peace and security in the member countries is an essential asset to further integration. So far, the incidences of internal or cross border conflicts have adversely affected intra regional trade. Hence, priority should be given to securing peace. As Udombana notes, African states must turn their swords into ploughshares, because the concept of a union will continue to be a façade in a continent that is plagued by conflicts. ${ }^{151}$

Apart from peace and stability, existence of good governance and democracy foster regional integration. One of the principles of good governance, legitimacy, entails the participation of all the citizens in decision making. Discussion on RECs in African countries is limited to government officials. Although the AU treaty recognizes 'the need to build a partnership between governments and all segments of civil society, in particular women, youth and the private sector, in order to strengthen solidarity and cohesion among our peoples ${ }^{152}$ this has not been achieved so far. Regional integration initiatives should thus be open for discussion among the private sector, non-governmental organizations and individuals in the countries. This enhances the feelings and thoughts of belongingness to wider regional and continental economic and political entities beyond national borders.

\footnotetext{
${ }^{150}$ Atieno Ndomo, (2009), Regional Economic Communities in Africa; A progress Overview, A study Commissioned by GTZ, p. 17.

151 Udombana, supra note 32, p. 225.

${ }^{152}$ Preamble of the AU treaty, paragraph 7.
} 
As indicated above, infrastructure is one of the factors that facilitate integration in the region. The continent is portrayed with absence of the requisite institutional and physical infrastructure to foster intra regional trade which affects its integration. Adequate infrastructure and services such as power generation, telecommunication, and distribution/ logistics services are essential to create conducive environment for business activities. ${ }^{153}$ The negative effect of inadequate infrastructure on integration is indeed recognized by the leaders of African states.

The transport and other infrastructure sectors have continued to enjoy a special place in the AUC Strategic Plan since 2004. ${ }^{154}$ In February 2009, for example, the AU Assembly of Heads of State and Government dedicated its meeting to a theme on development of transport and energy infrastructure in Africa. Consequently, it adopted a special Declaration directing the AU Commission and its partners to work on accelerating the implementation of major integration infrastructure projects in the continent as well as the formulation of the single Program for Infrastructure Development in Africa (PIDA). ${ }^{155}$ PIDA is an initiative led by the African Development Bank, the $A U$, and the NEPAD Secretariat which provides the common framework to build the infrastructure necessary for more integrated transport, energy, ICT and transboundary water networks to boost trade. ${ }^{156}$ These are commendable efforts in addressing the infrastructure challenges in the continent.

\section{Conclusion}

The pace and magnitude of actual success in Africa's economic integration are inadequate in comparison with the tone and content of the pledges expressed in various declarations and resolutions. This failure, however, has not stopped the discussion on and efforts toward regional integration in the continent. At sub-regional level, COMESA has furthered its integration and

153 Calvin Manduna, (2005), Assessing the Causes of Sub Saharan Africa's declining Exports: Addressing Supply side Constraints, Tralac Working Paper, p. 28.

154 Seventh Conference of African Ministers in Charge of Integration, (14-18 July 2014), Swaziland, Trade and Infrastructure, Department of Infrastructure and Energy, paragraph 20.

155 Id., paragraph 21.

${ }^{156}$ Seventh Conference of African Ministers in Charge of Integration, (14-18 July 2014), Swaziland, Programme for Infrastructure Development in Africa (PIDA): Addressing the Infrastructure gap in Africa to speed up Regional Integration, Department of Infrastructure and Energy, paragraph 6. 
turned into customs union in 2011 while the EAC is aspiring to launch monetary union soon. The discussion on tripartite free trade area among the eastern and southern African RECs COMESA, EAC and SADC has also transpired since 2008 and it is expected that it will come into effect in mid 2015.

Different attempts are also launched at the continental level through the African Union. However, a pragmatic pledge to regional integration requires realistic grass-root pursuits which go far beyond declarations and promises. Such pursuits clearly transcend the removal of tariff barriers. Efforts to overcome obstacles such as supply side constraints, lack of complimentarity of traded goods, and problems related to transport infrastructure and communication services are crucial. To this end, it is advisable to focus on strengthening the RECs and charting out the roadmap which facilitates the gradual merger of these smaller groupings.

There is also a need to address the challenges in the realms of laws and policies. Growing trade requires a significant enhancement of production of goods and services through institution building, good governance as well as the encouragement of domestic and foreign investment. This calls for conducive business environments and their corresponding harmonization at the level of neighboring member states. Such settings nurture and reinforce the fulfillment of mutual needs and win-win interests of member states in the course of sub-regional economic integration. Viable sub-regional integration can then eventually lead to regional integration and cooperation which enhances the continent's sustainable development by boosting intra regional trade maintained by a strong and viable commitment to implement it. This commitment is feasible if there is sense of belongingness of most individual persons residing in the individual member states of the integration scheme. As any effective system is an organic compound of its elements, the level of commitment and effective pursuits toward economic integration ultimately hinges on Africans at the grassroots who should participate in the making, operations and decisions of the RECs to which they belong. 